\title{
Indonesian primary care physician perception towards contraception usage: a review
}

\section{Budi I. Santoso, Raymond Surya*, Surahman Hakim}

Department of Obstetrics and Gynecology, Faculty of Medicine Universitas, Indonesia

Received: 28 December 2017

Accepted: 24 January 2018

\section{*Correspondence:}

Dr. Raymond Surya,

E-mail: raymond_s130291@yahoo.co.id

Copyright: (C) the author(s), publisher and licensee Medip Academy. This is an open-access article distributed under the terms of the Creative Commons Attribution Non-Commercial License, which permits unrestricted non-commercial use, distribution, and reproduction in any medium, provided the original work is properly cited.

\begin{abstract}
Background: Indonesian Health Profile (IHF) showed that Indonesian population reached 255.46 million people in 2015. A way to control population growth is through family planning (FP). This study aims to evaluate knowledge, attitude, and practice (KAP) of general practitioner in Indonesia regarding to contraception and postpartum contraception.

Methods: A cross sectional descriptive study to all internship doctors in Indonesia was held between July and August 2016. There were $8,10,9,6$ questions focusing on characteristics demographic, knowledge, attitude, and practice towards contraception including postpartum contraception, respectively. The inclusion criteria were all general practitioners who were doing the internship in Indonesia during this study. The exclusion criteria were general practitioners who postponed the internship due to any reasons. Descriptive statistics were used for data analysis using SPSS 23.0 for Windows.

Results: Most of them (56.4\%) had good knowledge, $97.4 \%$ respondents pointed out positive attitude, and $72.3 \%$ of them showed positive practice towards contraception. Meanwhile, the experience of inserting IUD, implant, and performing contraceptive injection was only $58.5 \%, 43.6 \%$, and $79.0 \%$; contributively.

Conclusions: Supervision training starting from contraceptive counselling to procedure of insertion on long acting and permanent methods (LAPM) should be conducted to allow quality contraceptive service in Indonesia.
\end{abstract}

Keywords: Attitude, Contraception, Knowledge, Practice

\section{INTRODUCTION}

Indonesian Health Profile (IHF) in 2015 showed that there was an increase of population growth between 3.34 and 3.70 million per year from 2010 to 2015 . It contributed to the Indonesian population of 255.46 million people in 2015. Population pyramid in Indonesia pointed out that the highest distribution was on younger population. It can impact to the population explosion in the next several years. ${ }^{1}$ One method to control the population growth is through family planning (FP). Indonesia regulation number 87 in 2014 stated that family planning is the way to limit number of children, spacing, and ideal age for pregnancy also delivery through promotion, protection, and assistance in appropriate to reproductive right to form quality family.

United Nations in 2013 described that contraceptive prevalence rate (CPR) in Indonesia was only $61.9 \%$ in 2012. ${ }^{2}$ The presentation of new contraceptive user compared to fertile aged couple in Indonesia was only $13.46 \%$ in 2015 lower than $16.51 \%$ in $2014 .^{1}$ The low rate of using contraceptive methods increased the risk for unwanted pregnancies, unintended births, and unsafe abortion which were related to the maternal and child morbidity also mortality. ${ }^{3}$ 
Several factors influencing CPR include patient preferences and health system factors which cover the contraception choice by government insurance. Additional contributing factor comes from information which women get from health professional. ${ }^{4}$ Saumya, et al had stated the association between quality of provided information and use of contraceptive methods. ${ }^{5}$ Knowledge of all aspects on contraception becomes a prerequisite for optimal decision and quality counseling allows women to choose methods of contraception in appropriate to their needs; thus, it will result better compliance. Effective counselling means that the provider can realize the client's preference and medical history related for each contraceptive methods. In Portugal, the CPR reached $85 \%$; however, the number of unintended pregnancy in contraceptive user was still high. ${ }^{6}$

Therefore, this study aims to evaluate knowledge, attitude, and practice (KAP) of general practitioner in Indonesia towards contraception and postpartum contraception.

\section{METHODS}

We conducted a cross sectional descriptive study to all internship doctors in Indonesia between July and August 2016. Internship doctors mean that the one who have graduated from medical school and they are doing a year service under supervision. We used total sampling through distributing online questionnaire. We showed the aim of this study in the beginning of the questionnaire and considered that the informed consent was signed by fulfilling all questions inside. There were 8 characteristics demographic questions. Meanwhile, to assess the KAP of general practitioners about contraception, we asked 10, 9, and 6 questions about knowledge, attitude, and practice of contraception including postpartum contraception, respectively. We adopted the questionnaire from several previously published studies. ${ }^{7,8}$ We developed the questions appropriate to the culture and then translated it into Indonesian language.

The knowledge of contraception was determined by several questions, such as source of information on contraception, methods of contraception and postpartum contraception, side effects of hormonal contraception, also series of statements related to contraception. We summed the total knowledge of known methods from contraception and postpartum contraception, also the best procedure time for inserting the IUD. Score of 11-14 was considered as good knowledge, 6-10 as fair knowledge, and less than 5 as poor knowledge. Meanwhile, we asked series of questions towards to their attitudes about contraception and postpartum contraception which focused on intrauterine device (IUD) and hormonal contraception. Total attitude score was the summation of confidence to counsel about contraception, the view of IUD and hormonal contraception, suggestion to use IUD compared to hormonal contraception, suggestion to insert
IUD directly after delivery, and the opinion of using hormonal contraception during lactation. The positive attitude was shown by score more than 13 ; in other way, they were regarded as negative attitude. The last section of questionnaire, we asked about practice towards contraception focused on their experience in providing contraception. We summed the practice statements of experience in inserting IUD and implant, suggestion to change to hormonal contraception, and counselling how important using postpartum contraception. Score more than 2 was considered as positive practice and the other one as negative practice.

The inclusion criteria were all general practitioners who were doing the internship in Indonesia during this study so that we hoped that they would have similar ability in the contraception service. The exclusion criteria were general practitioners who postponed the internship due to any reasons. We considered that respondents who finished this questionnaire had given their implied consent to this study.

\section{Statistical analysis}

Descriptive statistics were used for data analysis using SPSS 23.0 for Windows. Normality tests were performed using Kolgomorov-Smirnow for all demographic characteristic data. Descriptive analysis was presented in term of frequency, percentage, median, and minimummaximum. Knowledge, attitude, and practice scores were the independent variables in this study. Validity test with Pearson correlation ( $\mathrm{r}$ arithmetic more than $\mathrm{r}$ table) and reliability test with Cronbach's alpha $(>0.5)$ were done for questions to describe the KAP regarding contraception. We described all results in table; however, only valid and reliable questions were counted in and continued to Spearman correlation test to see the association between KAP. All p-values were 2-tailed and the significance level selected were lower than 0.05 .

\section{RESULTS}

Due to adoption of several questionnaires from other language, we performed the validity and reliability test. We recruited the first 30 respondents as the samples. Only 3/10 knowledge, 6/8 attitude, and 4/6 practice questions regarding to contraception were valid. However, we distributed all questions in tables and only valid and reliable questions were continued to be analyzed. We got 0.595 for Cronbach alpha of 13 valid questions.

In order to maximize the study participation and data collection, we sent request to fill out the online questionnaire through each internship region by sending message. During 2 months of spreading the online questionnaire, we got 195 respondents who finished answering all questions. In our prediction, there were around 3,000 general practitioners doing internship in a year. The mean age of respondents was 25.0 (SD 1.6) 
years with the range of 21-38 years old. Most of respondents $(86.7 \%)$ were graduating from medical school in 2015 so that on the period of the study, they were doing the internship (Table 1).

Table 1: Subject's characteristics participated in this study $(\mathrm{N}=195)$.

\begin{tabular}{|c|c|}
\hline Characteristics & $\mathbf{N}(\%)$ \\
\hline \multicolumn{2}{|l|}{ Age (years old) } \\
\hline Median (min-max) & $25(21-38)$ \\
\hline \multicolumn{2}{|l|}{ Religion } \\
\hline Muslim & $100(51.3)$ \\
\hline Catholics & $39(20.0)$ \\
\hline Christian & $40(20.5)$ \\
\hline Hindu & $8(4.1)$ \\
\hline Buddhist & $8(4.1)$ \\
\hline \multicolumn{2}{|l|}{ Marital status } \\
\hline Single & $164(84.1)$ \\
\hline Married & $30(15.4)$ \\
\hline Divorce & $1(0.5)$ \\
\hline \multicolumn{2}{|l|}{ Educational level } \\
\hline Bachelor degree/ medical doctor & $190(97.4)$ \\
\hline Master degree & $5(2.6)$ \\
\hline \multicolumn{2}{|l|}{ Medical school } \\
\hline Government & $116(59.5)$ \\
\hline Public & $79(40.5)$ \\
\hline \multicolumn{2}{|l|}{ Graduation year } \\
\hline 2013 & $5(2.6)$ \\
\hline 2014 & $10(5.1)$ \\
\hline 2015 & $169(86.7)$ \\
\hline 2016 & $10(5.1)$ \\
\hline N/A & $1(0.5)$ \\
\hline \multicolumn{2}{|l|}{ Internship region } \\
\hline Sumatera & $16(8.2)$ \\
\hline Java & $108(55.4)$ \\
\hline Bali and Nusa Tenggara & $27(13.9)$ \\
\hline Borneo & $9(4.6)$ \\
\hline Sulauwesi & $23(11.8)$ \\
\hline Papua & $12(6.2)$ \\
\hline \multicolumn{2}{|c|}{ Source of information on contraception } \\
\hline Formal education & $186(95.4)$ \\
\hline Congress & $54(27.7)$ \\
\hline Print/ electronic media & $61(31.3)$ \\
\hline Working place & $68(34.9)$ \\
\hline Others & $22(11.3)$ \\
\hline
\end{tabular}

In general, all respondents had ever heard about contraception and they knew well about the methods of contraception ( $>80 \%$ for each method).

Further question about postpartum contraception, the knowledge of respondents was not really good. Only $16.4 \%, 23.6 \%$, and $22.6 \%$ of them answered that implant, progestin injection, and mini pill; respectively, could be used as postpartum contraception. Meanwhile, they can answered correctly about several statements regarding natural, barrier, hormonal, and IUD (Table 2). Overall, most of them (56.4\%) had good knowledge about contraception and only $1.0 \%$ showed poor knowledge.

Table 2: Knowledge of respondents towards contraception $(\mathrm{N}=195)$.

\begin{tabular}{|c|c|}
\hline Statements & $\mathbf{N}(\%)$ \\
\hline \multicolumn{2}{|l|}{ The known methods of contraception* } \\
\hline Natural & $187(95.9)$ \\
\hline Barrier & $162(83.1)$ \\
\hline Hormonal & $192(98.5)$ \\
\hline Intrauterine device (IUD) & $191(97.9)$ \\
\hline Permanent & $180(92.3)$ \\
\hline \multicolumn{2}{|c|}{ The following statements are about contraception } \\
\hline $\begin{array}{l}\text { The use of IUD will increase the risk of } \\
\text { infertility - False }\end{array}$ & $175(89.7)$ \\
\hline $\begin{array}{l}\text { The use of IUD will increase the risk of } \\
\text { pelvic inflammatory disease compared to } \\
\text { other methods of contraception - True }\end{array}$ & $158(81.0)$ \\
\hline $\begin{array}{l}\text { High blood pressure is the absolute } \\
\text { contraindication for using hormonal } \\
\text { contraception - False }\end{array}$ & $110(56.4)$ \\
\hline $\begin{array}{l}\text { Condom is a protective contraception for } \\
\text { sexual transmitted disease (STD) - True }\end{array}$ & $189(96.9)$ \\
\hline $\begin{array}{l}\text { Coitus interruptus has the highest risk of } \\
\text { failure-False }\end{array}$ & $14(7.2)$ \\
\hline $\begin{array}{l}\text { Intrauterine device is safely inserted } \\
\text { between } 10 \text { minutes and } 48 \text { hours } \\
\text { postpartum-True* }\end{array}$ & $150(76.9)$ \\
\hline \multicolumn{2}{|c|}{ The following side effects of hormonal contraception } \\
\hline Menstrual cycle changes & $181(92.8)$ \\
\hline Headache & $112(57.4)$ \\
\hline Breast pain & $89(45.6)$ \\
\hline Body weight increase & $186(95.4)$ \\
\hline Blood pressure increase & $131(67.2)$ \\
\hline Sexual transmitted disease-False & $6(3.1)$ \\
\hline \multicolumn{2}{|c|}{ The known methods of postpartum contraception* } \\
\hline Amenorrhea lactation & $182(93.3)$ \\
\hline Permanent & $135(69.2)$ \\
\hline Intrauterine device & $181(92.8)$ \\
\hline Implant & $32(16.4)$ \\
\hline Progestin injection & $46(23.6)$ \\
\hline Mini pill & $44(22.6)$ \\
\hline Combination pill-False & $16(8.2)$ \\
\hline Combination injection-False & $17(8.7)$ \\
\hline
\end{tabular}

Regarding to attitude, $97.4 \%$ respondents pointed out positive attitude. Positive attitudes were indicated on several questions including sufficient knowledge about contraception $(77.4 \%)$, confidence to counsel patients $(74.9 \%)$, safety and effectivity of IUD (94.9\%), suggestion of IUD insertion directly in postpartum women (77.4\%). Meanwhile, most respondents described negative attitudes on statements such as IUD as abortifacient method (96.4\%), natural contraception better that other methods $(71.3 \%)$, and hormonal contraception during lactation $(73.8 \%)$ (Table 3$)$. 
Table 3: Attitude of respondents towards contraception ( $\mathrm{N}=195)$.

\begin{tabular}{|c|c|c|c|c|}
\hline Statements & $\begin{array}{l}\text { Strongly } \\
\text { disagree } \\
\mathbf{N}(\%)\end{array}$ & $\begin{array}{l}\text { Disagree } \\
\mathbf{N}(\%)\end{array}$ & $\begin{array}{l}\text { Agree } \\
\mathbf{N}(\%)\end{array}$ & $\begin{array}{l}\text { Strongly } \\
\text { agree } \\
\mathbf{N}(\%)\end{array}$ \\
\hline I have sufficient knowledge about methods of contraception & $2(1.0)$ & $42(21.5)$ & $136(69.7)$ & $15(7.7)$ \\
\hline I am confident to counsel about contraception* & $3(1.5)$ & $46(23.6)$ & $129(66.2)$ & $17(8.7)$ \\
\hline Intrauterine device is safe and effective* & $0(0)$ & $10(5.1)$ & $92(47.2)$ & $93(47.7)$ \\
\hline Intrauterine device is an abortifacient method & $170(87.2)$ & $18(9.2)$ & $5(2.6)$ & $2(1.0)$ \\
\hline Hormonal contraception is safe and effective* & $6(3.1)$ & $96(49.2)$ & $82(42.1)$ & $11(5.6)$ \\
\hline $\begin{array}{l}\text { In counselling, I suggest patients using IUD than hormonal } \\
\text { contraception* }\end{array}$ & $2(1.0)$ & $16(8.2)$ & $81(41.5)$ & $96(49.2)$ \\
\hline I believe that natural contraception is better than other methods & $47(24.1)$ & $92(47.2)$ & $43(22.1)$ & $13(6.7)$ \\
\hline I suggest postpartum women using IUD directly* & $6(3.1)$ & $38(19.5)$ & $88(45.1)$ & $63(32.3)$ \\
\hline I think that women can use hormonal contraception during lactation* & $73(37.4)$ & $71(36.4)$ & $42(21.5)$ & $9(4.6)$ \\
\hline
\end{tabular}

*Valid and reliable

Good knowledge and attitudes was in appropriate to positive practice $(72.3 \%)$. The experience of inserting IUD, implant, and performing contraceptive injection was described in $58.5 \%, 43.6 \%$, and $79.0 \%$; contributively. Meanwhile, most of respondents held counselling about contraception to patients (Table 4). Knowledge was correlated very weakly with attitude $(\mathrm{p}=0.007 ; \mathrm{r}=0.192)$ and no correlation to practice $(\mathrm{p}=0.105)$. Attitude had also very weak correlation to practice $(\mathrm{p}=0.001 ; \mathrm{r}=0.228)$.

Table 4: Practice regarding contraception $(\mathrm{N}=195)$.

\begin{tabular}{|ll|}
\hline Statements & $\mathrm{N}(\%)$ \\
\hline I have ever inserted IUD* & $114(58.5)$ \\
\hline I have ever inserted implant* & $85(43.6)$ \\
\hline $\begin{array}{l}\text { I have ever performed injection } \\
\text { I will counsel patients before offering } \\
\text { contraception to patients }\end{array}$ & $154(79.0)$ \\
\hline $\begin{array}{l}\text { I directly suggest changing to hormonal } \\
\text { contraception when there is cervical }\end{array}$ & $59(30.3)$ \\
\begin{tabular}{l} 
inflammation* \\
\hline $\begin{array}{l}\text { In antenatal care, I counsel to patients } \\
\text { how necessary to use postpartum } \\
\text { contraception* }\end{array}$
\end{tabular} \\
\hline *Valid and reliable & $157(80.5)$ \\
\hline
\end{tabular}

\section{DISCUSSION}

The limitation of our study is the small sample size of internship doctors around Indonesia. Apart from that, the data are based on self-report and it can make recall bias.

Meanwhile, we took respondents in similar condition, namely only internship doctors. Internship doctors are the general practitioners who has just graduated on average six months to a year before so that we can determine the quality of reproductive health education in their medical school. They have fresh memory about knowledge and similar experience on the health services. Apart from that, this is the first study in Indonesia which assess the primary care physician's KAP towards contraception.

Indonesian policy to support family planning 2020 (FP 2020) is through postpartum FP services as part of national childbirth insurance scheme. ${ }^{9}$ This policy has to be supported by health professionals offering contraception through their KAP. The lack of knowledge about contraception would potential affect providers' ability to provide quality contraceptive care to patients. It could prevent unintended pregnancy. ${ }^{10}$

As shown in Table 2, most respondents could answered correctly in several statements, especially about long acting and permanent methods (LAPM) and postpartum contraception. Only statement of high blood pressure as absolute contraindication on hormonal contraception was mostly wrongly answered by respondents (43.6\%). American Family Physician concluded that combined hormonal contraception is safely used in women with well-controlled hypertension; thus, it becomes relative contraindication for women having high blood pressure. ${ }^{11}$

Regarding attitudes, most respondents got information on contraception through formal education (95.4\%) and most of them showed positive attitudes to contraception, particularly in counselling patients. It was similar to study by Courtney AS, et al. ${ }^{12}$ which stated that their respondents felt receiving formal contraception education and considering contraception as being an important part of women's primary care. Apart from that, relationship between informative doctor and patient encounter would maximize efficacy of contraceptive use. Physicians hold important influence to the success of contraceptive methods.

Meanwhile, only $58.5 \%$ and $43.6 \%$ internship doctors had ever inserted IUD and implant. Most of them experienced contraception injection (79.0\%). This experience rate was not peculiar looking to the contraceptive device users in Indonesia. The majority of 
Indonesian women were using injection (47.78\%), followed by pill $(23.6 \%)$, intrauterine device (IUD) $(10.73 \%)$, implant $(10.58 \%)$, sterilization $(4.14 \%)$, and condom $(3.16 \%){ }^{1}$

Indonesia aims to broaden access and choice by strengthening public and private clinic services to offer LAPM. ${ }^{9}$ Therefore, there should be a training for internship doctors as primary health care in performing LAPM. In accordance with Ministry of Health Republic Indonesia Law number 10 in 2016 stated that there will be a plan, placement, evaluation, and monitoring of specialist doctor to the public hospital in district around Indonesia. ${ }^{13}$ This policy becomes the opportunity for specialist to train primary care professional involving midwives and primary care doctors to provide quality contraceptive service.

According to study by Budi IS, et al to pregnant women in Ende, they stated that primary health care as the main source of contraceptive information; thus, primary doctor and midwives were the target for training. ${ }^{14}$ Until 2015 , there were 109,597 general practitioners and 369,995 midwives registered in Indonesian Council. ${ }^{1}$ Although more than 100,000 health professionals got contraceptive training, the CPR in Indonesia was still low around $61.9 \%$ and high unmet need rate reaching $12.70 \%$. It indicated that supervision training should be conducted in contraception service under obstetrics and gynecology specialist who had certification of clinical training skills (CTS).

This training includes contraceptive counselling on discussion of topics which may constitute a barrier between physician and women to the procedure of insertion. Good counselling relies on KAP of physicians regarding wishes, beliefs, and behaviors. ${ }^{6}$

Study by Abby LS, et al described that the importance of effective contraceptive counselling by primary care physicians to improve the quality of service. ${ }^{15} \mathrm{We}$ hope that kind of training can be a solution of this problem to increase the internship doctor experience in inserting LAPM. Therefore, after finishing internship period, they would be qualified in providing contraception service in the primary health center.

\section{CONCLUSION}

Respondents has good knowledge, positive attitude, and practice of contraception. However, they lack of experience in inserting LAPM. Therefore, supervision training starting from contraceptive counselling to procedure of insertion on LAPM should be conducted to allow quality contraceptive service in Indonesia.

Funding: No funding sources Conflict of interest: None declared

Ethical approval: The study was approved by the Institutional Ethics Committee

\section{REFERENCES}

1. Ministry of Health of the Republic, Indonesia. 2015 Health profile Indonesia. Jakarta: Kementerian Kesehatan RI. 2016. Available at http://www.depkes.go.id/resources/download/pusdati n/profil-kesehatan-indonesia/profil-kesehatanIndonesia-2015.pdf

2. United Nations. World contraceptive patterns 2013. New York: United Nations. 2013. Available at http://www.un.org/en/development/desa/population/ publications/family/contraceptive-wallchart2013.shtml

3. Ahiadeke $\mathrm{C}$. Incidence of induced abortion in southern Ghana. Int Fam Plan Perspect. 2001;27(2):96-101.

4. Ebrahim SH, Anderson JE, Correa-de-Araujo R, Posner SF, Atrash HK. Overcoming social and health inequalities among U.S. women of reproductive agechallenges to the nation's health in the $21^{\text {st }}$ century. Health Policy. 2009;90(2-3):196-205.

5. RamaRao S, Lacuesta M, Costello M, Pangolibay B, Jones H. The link between quality of care and contraceptive use. Int Fam Plan Perspect. 2003;29(2):76-83.

6. Bombas T, Costa AR, Palma F, Vicente L, Sá JL, Nogueira AM, et al. Knowledge-attitude-practice survey among Portuguese gynaecologists regarding combined hormonal contraceptives methods. Eur $\mathbf{J}$ Contracept Reprod Health Care. 2012;17(2):128-34.

7. Rupley DM, Morhe ESK, Moyer CA, Dalton VK. Maternity care provider knowledge, attitudes, and practices regarding provision of postpartum intrauterine contraceptive devices at a tertiary center in Ghana. Int J Gynecol Obstet. 2015;128(2):137-40.

8. Hohmann HL, Cremer ML, Gonzalez E, Maza M. Knowledge and attitudes about intrauterine devices among women's health care providers in El Salvador. Pan Am J Public Health. 2011;29(2):198202.

9. Avenir Health. Family planning program effort scores in 2014: Indonesia. 2016. Available at http://www.track20.org/download/pdf/FPE\%20Polic y\%20Briefs \%202014/FPE\%20brief\%202014\%20Ind onesia.pdf

10. Dehlendorf C, Levy K, Ruskin R, Steinauer J. Health care providers' knowledge about contraceptive evidence: A barrier to quality family planning care? Contraception. 2010;81(4):292-8.

11. Bonnema RA, McNamara MC, Spencer AL. Contraception choices in women with underlying medical conditions. Am Fam Physician. 2010;82(6):621-8.

12. Schreiber CA, Harwood BJ, Switzer GE, Creinin MD, Reeves MF, Ness RB. Training and attitudes about contraceptive management across primary care specialties: A survey of graduating residents. Contraception. 2006;73:618-22.

13. Regulation of the Minister of Health of the Republic of Indonesia Number 10;2016. Available at 
http://www.depkes.go.id/resources/download/infoterkini/Permenkes_10_2017/Permenkes\%20no\%201 0\%20tahun\%202017\%20pengundangan.pdf

14. Santoso BI, Surya R, Christina A, Hayati F. Knowledge, attitude, and practice (KAP) of Contraception among Pregnant Women in Ende District, East Nusa Tenggara, Indonesia. J South Asian Federation Obstet Gynec. 2017;9(2):110-8.
15. Spencer AL, Bonnema R, McNamara MC. Helping women choose appropriate hormonal contraception: Update on risks, benefits, and indications. Am J Med. 2009;122(6):497-506.

Cite this article as: Santoso BI, Surya R, Hakim S. Indonesian primary care physician perception towards contraception usage: a review. Int J Reprod Contracept Obstet Gynecol 2018;7:811-6. 